\title{
DEVELOPMENT OF THE SUSTAINABILITY INDEX OF FARMS BASED ON SURVEYS AND FADN SAMPLE*
}

\author{
PIOTR SULEWSKI \\ ANNA KŁOCZKO-GAJEWSKA
}

\begin{abstract}
This methodical paper discusses the procedure for developing the farm sustainability index using data from surveys and accountancy data collected in the FADN system database. The research covered a total of 600 farms selected similarly to the selection method used in FADN (taking into account the economic size, production type and region). The structure of the sustainability index of farms uses variables characterizing the environmental, economic and social dimension of sustainability. In total, over 100 output parameters classified in 7 partial indices were used in the assessment of sustainability. The resultant distribution of individual partial indices and dimensions of sustainability indicates the diversity of the studied population in terms of considered parameters. At the same time, it was found that aggregation leads to the dominance of values close to the middle of the range of considered indices. The applied methodology allows to assess the sustainability of individual farms and their classification into groups of entities diversified by the degree of compliance with the principles of sustainable agriculture. The ability to measure and assess the sustainability of farms can be considered as the first step in the process of creating effective agricultural development support policies. The paper provides an opinion in the
\end{abstract}

\footnotetext{
* The study prepared as part of implementation of a research project financed by the National Science Centre No. 2015/19/B/HS4/0227.

Dr hab. Piotr Sulewski, Szkoła Główna Gospodarstwa Wiejskiego w Warszawie, Wydział Nauk Ekonomicznych, Katedra Ekonomiki i Organizacji Przedsiębiorstw, Zakład Organizacji i Zarządzania; ul. Nowoursynowska 166, bl. VII. pok. 106,02-787 Warszawa (piotr_sulewski@sggw.pl).

Dr Anna Kłoczko-Gajewska, Szkoła Główna Gospodarstwa Wiejskiego w Warszawie, Wydział Nauk Ekonomicznych, Katedra Ekonomii i Polityki Gospodarczej; ul. Nowoursynowska 166, bl. V. pok. 5, 02-787 Warszawa (anna_kloczko_gajewska@sggw.pl).
} 


\section{long-lasting discussion on the operationalization of the concept of sustainable development and ways to measure the degree of compliance of economic opera- tors' actions with the paradigm in question.}

Keywords: sustainable development, sustainable agriculture, measurement of sustainability.

JEL codes: Q01, Q12, Q56.

\section{Introduction}

The concept of sustainable development, usually referred to in Poland as zrównoważony rozwój ${ }^{1}$, has been permanently introduced to the language of economics and politics with the publication of the report of th UN World Commission on Environment and Development, chaired by Brundtland, Our Common Future (World Commission, 1987, p. 6). This document stressed the need for changes in the current model of economic development, pointing to the need for a more equitable distribution of the benefits of the exploitation of natural resources and conducting business in an environmentally friendly manner. It also formulated one of the most commonly cited definitions of sustainable development ${ }^{2}$, according to which it is "development that meets the needs of the present without compromising the ability of future generations to meet their own needs". In the context of this definition, it is particularly important to protect non-renewable natural resources being a source of raw materials for various sectors of economic activity. Although the issue of protection of resources is of fundamental importance for sustainable development, the idea itself is in fact of social nature, because, as Sachs (2011, p. 210) points out "Development goals are always social, there are environmental conditions which

\footnotetext{
${ }^{1}$ As indicated by Majewski (2008), the term "sustainable" is difficult to translate into Polish in one word. The English word "sustain" from which "sustainable" is derived means "to maintain, preserve or keep intact." According to the quoted author, Trwały Rozwój should refer to the sustainability of the basis of human activity (in the long term, the basis for the existence of mankind), which means that this term corresponds directly with the challenge that the philosophy of "sustainability" imposes on humanity - i.e. to meet the needs of the present ensuring no smaller ability of future generations to meet their own needs. It is connected with the "right to dispose of undamaged environmental resources". The term zrównoważony rozwój, which has become popular both in Polish literature on the subject and in various documents (including the Constitution of the Republic of Poland), correctly understood, does not contradict the general idea of "sustainability," although it insufficiently emphasises the essence of the concept. However, the concept of równowaga (which is widely used in economics) in the context of "sustainable development" can lead to overinterpretation and the search for equality between the environmental, economic and social dimensions. As Zacher notes (2008), the terms zrównoważony and zrównoważenie can emphasise certain balance between nature, economy and man only in a metaphorical sense, in no way literal. Despite the popularisation of the term zrównoważony, part of researchers (e.g. Zacher, 2008; Lusawa, 2012; Majewski, 2008; Żylicz, 2008) uses the term trwały, which seems to better reflect the principles of this idea. Taking the above arguments into account (discussed in more detail in the studies of the authors cited), the paper adopted the convention based on the use of the term trwały rozwój and trwałe rolnictwa with reference to foreign literature on the subject and own thoughts, while in case of Polish literature on the subject, the terms originally used by the authors of individual studies were used (zrównoważony or trwały). ${ }^{2}$ It is worth noting that since the publication of the Brundtland report, many other definitions of trwaty/ zrównoważony rozwój or "sustainable development" have been formulated.
} 
need to be respected, and in order to be able to do anything, the proposed solutions must be economically feasible". The achievement of the objectives of sustainable development is, therefore, possible only through the integration of the economic, environmental and social factors in the economic decision-making process (Emas, 2015). In practice, these three groups of factors are identified with three dimensions of sustainability (environmental, economic and social).

\section{Measures of sustainable development - literature review}

Gorlach, Klekotko and Nowak (2013, p. 15) argue that sustainable development is not so much a description or pursuit of a specific state of society as "rather a state of permanent debate, a constant analysis of critical considerations", which are to some extent tools for creating the right policy for broadly understood development. From the very beginning, development of the discussion on the concept of "sustainability" has been accompanied by the search for measures to assess the conformity of reality with the philosophical assumptions defining the framework of this construct. As Majewski (2008) points out, the possibility of measuring the phenomena determining the state of sustainability and its change is a necessary condition for the practical implementation of the principles of sustainable development. According to Olsson, Bradley, Hilding-Rydevik, Ruotsalainen and Aalbu (2004, as cited in Majewski, 2008,p. 60), sustainability indices are "quantitative tools for analysing changes, measuring and informing about the progress in the transition to the use and management of economic, social, institutional and natural resources, more consistent with the paradigm of Sustainable Development".

Due to the multidimensional nature of the concept of sustainable development, the measurement of sustainability is made on a different scale and in a different range. In practice, the structure of sustainability indices assumes a hierarchical structure, i.e. one of three dimensions of sustainability is divided into several relatively different analytical areas) and possibly sub-areas, and then each area is assigned a measurable parameter. The sum of parameters assigned to individual areas, aggregated in a different way, is then the basis for a synthetic assessment of sustainability in the analysed dimension. Schematically, this approach is reflected in Figure 1.

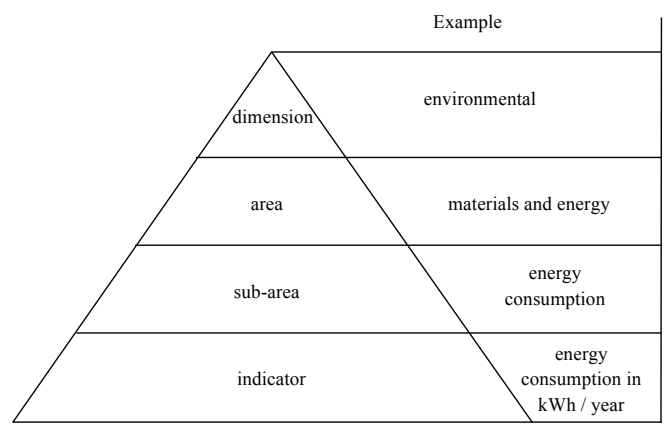

Fig. 1. A hierarchical approach to creating sustainability indices.

Source: de Olde, Oudshoorn, Sørensen, Bokkers and de Boer (2016). 
The literature on the subject offers a long list of various types of indices to measure individual aspects of sustainability. These indices differ, e.g. in the degree of complexity, calculation methodology, construction method or territorial scope of matching, etc. In general, three basic criteria for the division of sustainability indices can be indicated, i.e. the normative criterion (distinguishing indices measuring the environmental, economic and social dimensions), the spatial criterion (distinguishing local, regional and national analysis indices) and the time criterion (indicating a short and long perspective) (Zhen and Routray, 2003; Hayati, Ranjbar and Karami,2010). The indices which can be found in the literature on the subject can refer to macro-, meso- and microeconomic dimensions. The macro dimension applies to entire economic systems, the meso dimension can refer to sectoral analyses, and the micro dimension to the analysis of individual economic units.

Most often, the assessment of sustainability of farms takes into consideration the agroecological, economic and social criteria (Harasim, 2014; Baum, 2011). An exceptionally large number of proposals for indices measuring sustainability in agriculture refer to the environmental (agro-ecological) dimension. The queries of the most common approaches to the analysis of the environmental dimension of sustainability of agriculture made by various authors indicate that, from the perspective of farms, the usually assessed parameters include the problem of soil erosion, soil quality, water quality, quality of farming practices, fertilizer use, crop rotation, growing methods, pesticide use, climate change trends, renewal of organic matter in the soil, covering of soil with vegetation index, etc. (der Werf and Petit, 2002; Hayati, 2017; Kuś and Krasowicz, 2001). It seems that the analyses of sustainability in agriculture refer to the social and economic dimension less frequently. In the former case, usually the sustainability assessment takes into account the level of education, agricultural skills and experience, family status, ways of supporting decision making, living conditions, involvement in social affairs, safety, etc. (Hayati, 2017). Regarding the economic dimension, the most frequently quoted measures include productivity, labour productivity, efficiency, agricultural income or profit, income from other sources than the farm, production potential as measured by, for example, assets held, etc. (Hayati, 2017). As Krasowicz (2009) emphasises, the economic assessment plays a complementary role in agricultural research and is aimed mainly at the objectivisation and support of solutions offered to agricultural practice. The importance of perception of various phenomena occurring in agriculture and its environment by farmers for the possibility of implementing the principles of sustainable development, as well as the fundamental role of knowledge and education, are also emphasised more and more often (Carreón, René, Niels and van Haren, 2011). As stressed by Sabiha, Salim, Rahman and Rola-Rubzen (2016), farmers' actions depend on their environmental awareness, therefore, it is reasonable to include variables characterising the environmental perception of farmers in the analyses. Even though there are numerous examples of applications of indices relating to individual dimensions of sustainability in the literature on the subject, only some of them are comprehensive and include the aggregation of many indices. It is worth noting that, as emphasised by Kuś and Krasowicz (2001), a farm is an organic whole, hence its systemic perception is justified. 
In Poland, the issue of measuring the sustainability of farms was examined, for instane, by authors such as Majewski (2008), who proposed a comprehensive measure of sustainability - the Synthetic Farm Sustainability Index, Wrzaszcz $(2012,2013)$, who assessed the level of sustainability of farms using FADN data, or Baum (2011), who proposed a system of indices allowing for the possibility of rewarding farmers for the production of public goods. While constructing the aggregate sustainability index, Majewski (2008) based on a list of 56 parameters, whose value was determined on the basis of data obtained during interviews with farmers. Both continuous and stepwise variables (quantitative and qualitative), which were aggregated using the multiple weights method, were used here. This analysis was carried out with the distinction of five dimensions of sustainability considered at the farm level (i.e. the ecological, social, and economic dimension, the quality of the production space, as well as organisation and management). One of the examples of a comprehensive approach to measuring the sustainability of farms in Polish literature on the subject is the method proposed by Baum (2011), who defined a list of several dozen variables (indicators) used to assess agroecological sustainability ( 21 indicators), economic sustainability (6 indicators), social sustainability (14 indicators). On the basis of expert assessments, this author assigned scores on a different scale to each indicator. Analyses carried out using the RISE (Response-Inducing Sustainability Evaluation) model (Häni et al., 2003), described in works of authors such as Feledyn-Szewczyk and Kopiński (2015) or Bojarszczuk, Księżak and Feledyn-Szewczyk (2017), can be also seen as a complex synthetic assessment. The RISE model, used by the above-mentioned authors, takes into consideration 12 indicators, which were calculated on the basis of over 60 parameters (regarding energy, water, soil, biodiversity and fertilizer management, plant protection, waste management, economic efficiency and stability, and social conditions of employees). In this method, the state (current situation) and pressure are determined separately for each indicator on the basis of various parameters (state and pressure) (Bojarszczuk et al., 2017).

The issue of measuring "sustainability" using a smaller number of indices was explored by authors such as Kania and Kapłon (2014), who performed the assessment of sustainability using surveys (interview questionnaire) on the basis of 5 environmental criteria, one economic and one social criterion. The surveys were used to determine the sustainability of different types of farms by Harasim and Włodarczyk (2016), who carried out the assessment using 8 ecological, 4 economic and 3 social indicators. On the other hand, Bojarszczuk (2014) indicated an average low level of sustainability of dairy farms, based on selected production and agroecological indicators.

The assessment of environmental sustainability with the use of the synthetic index (including variables available in the FADN, such as stocking density, fertilizer use intensity, consumption of plant protection products, energy intensity of production and relation of forested area to utilized agricultural areas) on the EU scale was also conducted by Czyżewski, Matuszczak and Guth (2017) using the Hellwig's method. The assessment of sustainability of agriculture on a national scale was also 
conducted by Toczyński, Wrzaszcz and Zegar (2013) using data from mass statistics resources. In this case, the assessments were carried out in a dynamic and static dimension, based on 60 indicators for the dynamic dimension and a small number of environmental indicators for the static dimension. The obtained results indicated an ambiguous image of sustainability of Polish farms.

As it follows from the conducted literature review, so far it has not been possible to develop a uniform concept for measuring sustainability of farms. As Harasi (2012, p. 52) points out, "the names and scopes of assessment of sustainable development are different, there is no uniform and universal approach to measuring sustainability". However, a large part of the studies is based on aggregation of diagnostic variables into 3 indices corresponding to three dimensions of sustainability. This applies to many works of both the above-mentioned national authors, and foreign authors (e.g. Gómez-Limón and Sanchez-Fernandez, 2010; Meulen van der, Dolman, Jager and Venema, 2014; Longhitano, Bodini, Povellato and Scardera, 2012), although one can also find studies in which one dimension of sustainability is assessed (e.g. Rigby, Woodhouse, Young and Burton (2001) analysed the sustainability of farms through the prism of agro-environmental variables, and Wrzaszcz (2013) focused on 2 dimensions). According to Harasim (2012), works in the field of assessment of sustainable development of agriculture, conducted by research institutes at the farm level, focus mainly on the economic and ecological criterion, while the social dimension refers more to the level of a region or a country.

Ciegis, Ramanauskiene and Martinkus (2009) emphasise that the concept of sustainable development is multidimensional and its analysis should be systemic, because what matters in the final assessment is not so much the level of individual parameters as the total result of the processes taking place in all the components of sustainability. Sustainability (or lack thereof) is not a simple sum of individual parameters or elements, but also the effect of their mutual interactions. According to the authors quoted above, the one-dimensional approach (e.g. concentration on the environmental dimension) is valuable, as it facilitates the identification of problems relating to individual dimensions of sustainable development, but it refers to sustainability as a feature of an object or economic system to a small extent.

Even though many measures of sustainability have been developed in the area of agriculture so far, the scope of their use in the economic practice of agriculture still remains quite limited (de Olde et al., 2016). Changes occurring in agriculture are increasingly related to the necessity to implement the principles of sustainable development (Krasowicz and Kuś, 2010). This means that there is constantly a need to look for methods of measuring and assessing sustainability which would show a higher degree of usability and allow for more precise assessment of signalled phenomena. 


\section{Methodology}

The purpose of this article was to develop a comprehensive index of farm sustainability. The article is of a methodical nature, but to verify the correctness of selected variables (which were to form the index being created), empirical data was used to determine whether they significantly differentiate the studied collectivity.

Two basic sources of data were used in the conducted research, i.e. the FADN database (Farm Accountancy Data Network) and data obtained using the diagnostic survey method and the targeted interview technique. Surveys, which were carried out in 2017, included a sample of 600 farms from all farms participating in the FADN. The FADN data came from 2015. Objects for research were selected using the layered-random selection procedure, which included 4 layers due to the specialisation criterion, 3 layers due to the standard output criterion, 4 layers corresponding to the regions. The number of examined farms in individual layers was determined using the Neyman's method (Wąs, 2013) in a manner analogous to that used in determining the size of the FADN sample ${ }^{3}$. Interviews with farmers were carried out by advisers from agricultural advisory centres, who coordinate data collection in the framework of the FADN system. The questionnaires filled in by the advisers were combined with the relevant accounting data in the FADN database. Interviews with farmers made it possible to expand the set of variables available in the FADN database with a number of social and environmental parameters which were used to construct a comprehensive sustainability index, while financial and production data available in the FADN database was used primarily to assess economic sustainability.

\section{Creating a sustainability index}

As indicated by Gómez-Limón and Sanchez-Fernandez (2010), the methodology of development of indices includes four basic stages, i.e. selection of variables (acquirable and adequate to the description of the phenomenon), their normalisation in order to bring all parameters to a comparable level, possible assignment of weights to individual variables (partial indices), and aggregation of variables (partial indices).

The basis for estimating the value of the sustainability index was a set of 109 individual output parameters derived from the FADN database and data collected during interviews with farmers. Only those parameters which could be assigned

\footnotetext{
${ }^{3}$ The sample selected for research has a smaller size than the FADN sample, however, the adopted farm selection procedure is analogous to that used in the FADN, and includes the same information. The selected sample has the same structure as the FADN sample, with each layer represented by a smaller number of objects. As a result of application of the above-mentioned procedure, described in more detail in the study by Wąs (2013), it can be concluded that the probability of finding farms from the population covered by the FADN observation in the sample is known, which is one of the conditions of representativeness of the sample. However, it should be emphasised that the representativeness in the FADN concerns only three criteria (type, economic size and region). The applied approach has the character of a "two-phase sampling" and is described in the statistical literature on the subject (Kalton, 1983; Cochran, 1977; OECD, 2002). In the context of the above, it seems justified to assume that the "sample from the sample" maintains the characteristics of the main sample.
} 
a specific analytical value and which could be considered as unambiguously representing a specific area in each dimension of sustainability were selected for the study. The list of parameters to be included in the study was developed based on literature on the subject, in particular a review study by Hayati (2017), which, due to the date of publication, can be considered one of more comprehensive works on sustainability indices used in the assessment of farms. The formally applied research procedure correspond to the model of creating aggregate sustainability indices, described in the literature on the subject, which can be represented by the following formulas (Geniaux, Bellon, Deverre and Powell, 2009):

Aggregate index: $A=f(M)$

Indices of sustainability dimensions: $M=\left(m_{l}, \ldots, m_{k}\right)$; $g d z i e: m_{k}=h(Y)$

Partial indices: $Y=\left(y_{1}, \ldots, y_{i}\right)$; gdzie: $y_{i}=h(X)$

Diagnostic variables: $X=\left(x_{1}, \ldots, x_{n}\right)$ gdzie: $x_{i}=g(Z)$

Output parameters: $Z=\left(z_{1}, \ldots, z_{p}\right)$

\begin{tabular}{|} 
OUTPUT PARAMETERS \\
data from the interview questionnaire + FADN data (109 individual variables) \\
Rescaling to the 0-1 range (and aggregation of \\
"monothematic" parameters) \\
\hline $\begin{array}{c}\text { DIAGNOSTIC VARIABLES } \\
\text { (51 diagnostic variables scaled to the 0-1 range) }\end{array}$ \\
\begin{tabular}{|c|c|}
\hline Aggregation of diagnostic variables to the form of partial indices (by \\
calculating mean values)
\end{tabular} \\
\hline \\
\hline \\
(7 indices scaled to the 0-1 range) \\
\hline PARTIAL INDICES \\
\hline Agro-environmental & Economic and production & Social \\
\hline
\end{tabular}

Fig. 2. Diagram of the method of conducting research.

Source: own study.

Individual output parameters $(Z)$ were the basis for the estimation of 51 diagnostic variables $(X)$, whose value in some cases corresponds to the output parameters, and in some is a complex variable, estimated on the basis of several output parameters related to a specific phenomenon (in this study called "monothematic parameters"). ${ }^{4}$ The aim of such action was to avoid giving too much weight to some problems by placing too many diagnostic variables for the assessment of

\footnotetext{
${ }^{4}$ For example, such a procedure was used to assess the correctness of use of a sprayer, which was determined based on 4 output parameters ("monothematic" - i.e. related to only one aspect of companies' operations).
} 
only one phenomenon in the sustainability indices. Only parameters with a fairly low degree of correlation $(<0.4)$ were selected for the construction of individual aggregate variables, so that each element included in indices with a higher degree of aggregation carried an additional layer of information. Diagnostic variables were then aggregated into 7 partial sustainability indices $(Y)$. In the final phase of the research process, the above-mentioned partial sustainability indices were aggregated to three dimensions of sustainability $(M)$ (economic, environmental, social) and aggregate index $(A)$. Figure 2 illustrates this procedure, and the relations between individual diagnostic variables, partial indices and analysis dimensions are presented in Tables 1, 2 and 3.

All output parameters and diagnostic variables selected for the construction of sustainability indices were scaled to the 0-1 range, whereas it should be emphasised that the collected research material included various types of measurement scales, which necessitated the use of different scaling techniques. The discussion on the methods of normalisation and standardisation of partial parameters used in the creation of aggregate indices of farm sustainability can be found in the studies of authors such as, for example, Geniaux et al. (2009), Latruffe, Diazabakana, Bockstaller, Desjeux and Finn (2016), Salzman (2003), or in the broader context of a general classification of farms in the work of Binderman, Borkowski and Szczęsny (2009). In the case of continuous variables measured on a quotient scale (main data from the FADN database, e.g. production value), the transformation was made by dividing the data set into 10 ordered sections using the quantiles (deciles) method. Individual deciles of the distribution of a given variable were assigned point scores from the 0-1 range (values of the variable between the ninth and tenth decile were assigned 1 point, values between the ninth and eighths 0.9 point, etc.). The approach applied at this stage was of a non-model nature, since it is difficult to determine objectively the optimal value in relation to the variables used. The value of individual deciles was determined in accordance with the general formula for calculating quantiles (Ostasewicz, Rusnak and Siedlecka, 2011):

$$
Q_{k}=x_{Q k}+\frac{N_{Q k}-\sum_{i=1}^{k-1} n_{i}}{n_{m}} \cdot i_{Q k}
$$

$Q_{k} \quad$ - the symbol of k-th decile;

$k \quad-$ the number of the range (class) in which the corresponding decile follows;

$X_{Q k}-$ the lower limit of a given range (class);

$N_{Q k}$ - the position of a given decile calculated according to the formula $\frac{k N}{10}$; where

$N$ - general collectivity size;

$N \quad \sum_{i=1}^{k-1} n_{i}-$ the number cumulated to the range preceding decile;

$i_{Q k} \quad-$ the span of the ranges in which the right deciles are located. 
The use of the deciles method eliminated the need for expert assessment of the level of phenomena described by continuous variables, and at the same time ensured a fairly even distribution of the created index. The disadvantage of the approach used is the relative nature of the classification (the non-model approach) - even farms with objectively poor results could theoretically obtain a high value of the index, as the distribution is forced (but this problem also applies to other methods of normalisation).

In the case of variables measured on an ordinal scale (e.g. assessments of various phenomena carried out by farmers during interviews using the Likert scale, education, etc.), the principle of dividing the target distance (the range from 0 to 1 ) into equal sections in the number resulting from the structure of the question included in the questionnaire ${ }^{5}$. A similar principle was applied for variables requiring expert assessment (e.g. referring to the correctness of agricultural practice), if it was possible to graduate the correctness of responses and the resulting distribution could be considered substantively justified ${ }^{6}$ (the model approach). In such cases, the scale of correctness of answers was established before the test was carried out, during the construction of the interview questionnaire (based on the literature that was the source of inspiration for the question, e.g. MRiRW and MŚ, 2004; Majewski (ed.), 1997; Majewski, 2001). An analogous procedure was applied in the case of dichotomous variables, while the expected (from the point of view of sustainability) nature of the phenomenon was assigned to the value of 1 , and the remaining cases to the value of 0 .

Aggregation of output parameters and diagnostic variables, followed by aggregation of partial indices of sustainability, was carried out by calculating mean values (according to the diagram shown in Fig. 2). Due to this approach, at every stage of the analysis variables which formed more complex (aggregate) measures assumed the same weight (more widely, the issues of weighing partial indices when creating the aggregate sustainability index are discussed by such authors as Geniaux et al., 2009; Salzman, 2003). When it was not possible to calculate the given output parameter (diagnostic variable, partial index) on a given farm, the value of the higher order index was calculated on the basis of fewer variables (the lack of weights eliminated the problem of the importance of a given parameter in a more aggregate index). The procedures for determining the sustainability index were not differentiated due to the production type - in the absence of some variables in certain production types (e.g. data on livestock production), calculations were made on the basis of fewer variables.

Detailed information on variables used for the construction of individual indices is provided in Tables 1,2 and 3. The clear advantage of environmental components results from the fact that agriculture has a major impact on the quality of the natural

\footnotetext{
${ }^{5}$ For example, with the seven-level Likert scale (0-6 range), in the original question, the target range of 0-1 was divided into sections of 0.15 (the last section 0.2), applying the principle that the highest score in the questionnaire is 1 point to the value of the index, another 0.85 , etc.

${ }^{6}$ For example, with four levels of the phenomenon which can be substantively put in order, the most correct answer was given 1 point, the second 0.75 , etc.
} 
environment, and the plurality of various practices requires reference to various aspects of agricultural activity. At the same time, lack of due care for the environment may significantly reduce the production potential of the farm (e.g. soil quality).

Table 1

Register of variables used in the construction of the farm sustainability indexagro-environmental dimension

\begin{tabular}{|c|c|c|}
\hline Partial index & Diagnostic variable & Output parameter (basis for estimating the variable) \\
\hline \multirow{13}{*}{$\begin{array}{l}\text { Indicator } \\
\text { of the } \\
\text { correctness } \\
\text { of agricultural } \\
\text { practice } \\
\text { in plant } \\
\text { production }\end{array}$} & Soil examination & Frequency of soil examination. \\
\hline & $\begin{array}{l}\text { Parameters of chemical } \\
\text { plant protection }\end{array}$ & $\begin{array}{l}\text { Evaluation of the degree of taking into account various } \\
\text { parameters of the chemical plant protection treatment } \\
\text { by the farmer (wind, temperature, humidity, rainfall } \\
\text { probability). }\end{array}$ \\
\hline & $\begin{array}{l}\text { The basis for determining } \\
\text { the mineral fertilisation } \\
\text { dose }\end{array}$ & $\begin{array}{l}\text { The dominant premise of the decision on the fertilisation } \\
\text { dose (fertilising plans, manufacturer's recommendations, } \\
\text { adviser's opinion, knowledge of plant needs). }\end{array}$ \\
\hline & Incorporating manure & $\begin{array}{l}\text { The time that usually passes from the application } \\
\text { to the incorporation of organic fertilisers. }\end{array}$ \\
\hline & Catch crops & The practice of catch crops. \\
\hline & $\begin{array}{l}\text { Rules for plant } \\
\text { selection }\end{array}$ & $\begin{array}{l}\text { The dominant premise of plant selection (crop rotation, } \\
\text { succession conditioned by economic and natural reasons, } \\
\text { succession adapted to current needs). }\end{array}$ \\
\hline & $\begin{array}{l}\text { Agri-environmental } \\
\text { programmes }\end{array}$ & Participation in any agri-environmental programme. \\
\hline & $\begin{array}{l}\text { Methods of plant } \\
\text { protection }\end{array}$ & $\begin{array}{l}\text { Aggregate variable covering the meaning of various } \\
\text { protection methods (mechanical, chemical, biological, } \\
\text { integrated) in protection against pests, diseases } \\
\text { and weeds. }\end{array}$ \\
\hline & $\begin{array}{l}\text { The basis for the decision } \\
\text { on the chemical plant } \\
\text { protection treatment }\end{array}$ & $\begin{array}{l}\text { Aggregate index covering the meaning of various } \\
\text { premises in a decision about a chemical plant protection } \\
\text { treatment against pests, diseases and weeds. }\end{array}$ \\
\hline & $\begin{array}{l}\text { Correctness of the use } \\
\text { of the sprayer }\end{array}$ & $\begin{array}{l}\text { Aggregate index including information on the frequency } \\
\text { of calibrating the sprayer, the parameters determining } \\
\text { the type of sprayer, the application of drift reducing } \\
\text { nozzles and the time of the treatment. }\end{array}$ \\
\hline & Incorporation of straw & $\begin{array}{l}\text { The use of incorporation of straw (with the addition } \\
\text { of nitrogen fertilisers, without fertilisers). }\end{array}$ \\
\hline & $\begin{array}{l}\text { Prevention of loss } \\
\text { of water from soil }\end{array}$ & $\begin{array}{l}\text { Application of techniques preventing the loss of water } \\
\text { from soil. }\end{array}$ \\
\hline & Seeds & $\begin{array}{l}\text { Estimated share of seed from various sources (certified, } \\
\text { own treated, untreated, from another farmer) in the seeds. }\end{array}$ \\
\hline
\end{tabular}


cont. Table 1

\begin{tabular}{|c|c|c|}
\hline Partial index & Diagnostic variable & Output parameter (basis for estimating the variable) \\
\hline \multirow{9}{*}{$\begin{array}{l}\text { Indicator of } \\
\text { the correctness } \\
\text { of practice } \\
\text { in livestock } \\
\text { production }^{\mathrm{a}}\end{array}$} & $\begin{array}{l}\text { Conditions } \\
\text { in the livestock building }\end{array}$ & $\begin{array}{l}\text { Aggregate index including assessment of conditions } \\
\text { in the livestock building in terms of temperature, } \\
\text { dustiness, humidity, light, ammonia aroma. }\end{array}$ \\
\hline & Isolation of animals & $\begin{array}{l}\text { Assessment regarding the isolation of sick animals } \\
\text { from healthy ones. }\end{array}$ \\
\hline & Access to water & $\begin{array}{l}\text { Assessment of water availability in the animal } \\
\text { accommodation. }\end{array}$ \\
\hline & Slipperiness of floors & $\begin{array}{l}\text { Assessment of slipperiness of floors in the livestock } \\
\text { building from the point of view of injury risk. }\end{array}$ \\
\hline & $\begin{array}{l}\text { Aggressiveness } \\
\text { of animals }\end{array}$ & $\begin{array}{l}\text { Assessment of the occurrence of aggressive behaviour } \\
\text { of animals resulting from stressful living conditions. }\end{array}$ \\
\hline & Access to feed & $\begin{array}{l}\text { Assessment of simultaneous access to feed } \\
\text { for the whole herd. }\end{array}$ \\
\hline & Pens & $\begin{array}{l}\text { Having separate pens for sows with piglets to prevent } \\
\text { crushing. }\end{array}$ \\
\hline & Disinfection of rooms & $\begin{array}{l}\text { Assessment of the frequency of disinfection of livestock } \\
\text { buildings. }\end{array}$ \\
\hline & Intensity of stocking & $\begin{array}{l}\text { Assessment of livestock production intensity compared } \\
\text { to the value } 150 \mathrm{LU} / 100 \mathrm{ha}\end{array}$ \\
\hline \multirow{3}{*}{$\begin{array}{l}\text { Environmental } \\
\text { perception } \\
\text { indicator }\end{array}$} & $\begin{array}{l}\text { Impact of agriculture } \\
\text { on the environment }\end{array}$ & $\begin{array}{l}\text { Assessment of the awareness of impact of agricultural } \\
\text { activity on soil, climate, landscape, biodiversity, } \\
\text { air and water. }\end{array}$ \\
\hline & $\begin{array}{l}\text { Knowledge of the concept } \\
\text { of sustainable agriculture }\end{array}$ & $\begin{array}{l}\text { Assessment of the farmer's understanding of the concept } \\
\text { of sustainable agriculture. }\end{array}$ \\
\hline & $\begin{array}{l}\text { Environmental } \\
\text { requirements }\end{array}$ & $\begin{array}{l}\text { Assessment of the legitimacy of meeting environmental } \\
\text { requirements by farmers. }\end{array}$ \\
\hline
\end{tabular}

a "Indicator of the correctness of practice in livestock production" was taken into account only in the case of farms with animals.

Source: own study.

Table 2

Register of variables used in the construction of the farm sustainability indexeconomic and production dimension

\begin{tabular}{|c|c|c|}
\hline Partial index & Diagnostic variable & Output parameter (basis for estimating the variable) \\
\hline \multirow{9}{*}{$\begin{array}{l}\text { Economic } \\
\text { potential } \\
\text { indicator }\end{array}$} & Property & Value of the farm's assets. \\
\hline & Labour productivity & Value of production per one full-time worker. \\
\hline & Production value & Absolute farm production value. \\
\hline & Area & Utilised agricultural area. \\
\hline & Work profitability & Income of a farm per one full-time worker. \\
\hline & Return on capital & Income of a farm per one zloty of assets. \\
\hline & Stability of income & $\begin{array}{l}\text { Assessment of income stability made by the farmer } \\
\text { on the Likert scale. }\end{array}$ \\
\hline & $\begin{array}{l}\text { Independence of income } \\
\text { from financial support }\end{array}$ & The relation of operating subsidies to farm income. \\
\hline & Financial independence & Share of equity in the farm's assets. \\
\hline
\end{tabular}


cont. Table 2

\begin{tabular}{|c|c|c|}
\hline Partial index & Diagnostic variable & Output parameter (basis for estimating the variable) \\
\hline \multirow{6}{*}{$\begin{array}{l}\text { Production } \\
\text { potential } \\
\text { indicator }\end{array}$} & Soil quality & Soil bonitation index. \\
\hline & Risk of water and wind erosion & Share of land at risk of erosion. \\
\hline & Water conditions & $\begin{array}{l}\text { Share of land with correct water conditions } \\
\text { and periodically over-dried and with excess water. }\end{array}$ \\
\hline & Content of nutrients in soil & Share of soil with different stock levels. \\
\hline & Soil acidification & Share of soil with different $\mathrm{pH}$ levels. \\
\hline & Natural sites & $\begin{array}{l}\text { The relation of the area of natural sites (afforestation, } \\
\text { overgrowth, unused areas, swamps, hedges, etc.) } \\
\text { to the utilized agricultural area. }\end{array}$ \\
\hline
\end{tabular}

Source: own study.

Table 3

Register of variables used in the construction of the farm sustainability indexsocial dimension

\begin{tabular}{|c|c|c|}
\hline Partial index & Diagnostic variable & Output parameter (basis for estimating the variable) \\
\hline \multirow{4}{*}{$\begin{array}{l}\text { Indicator } \\
\text { of living } \\
\text { conditions }\end{array}$} & Sewage system & $\begin{array}{l}\text { Assessment of the way sewage is discharged from the } \\
\text { household (sewerage system, cesspit, etc.). }\end{array}$ \\
\hline & Gas system & Evaluation of access to the gas system. \\
\hline & Location & $\begin{array}{l}\text { Aggregate variable including the assessment of time and } \\
\text { difficulties to reach facilities such as: primary care doctor, } \\
\text { hospital, primary/high school, AAC, gimina office, cultural } \\
\text { institutions. }\end{array}$ \\
\hline & Housing conditions & $\begin{array}{l}\text { Self-assessment of housing conditions } \\
\text { using the Likert scale. }\end{array}$ \\
\hline \multirow{7}{*}{$\begin{array}{l}\text { Mental } \\
\text { comfort } \\
\text { indicator }\end{array}$} & Social status & Self-assessment of the affluence of the agricultural family. \\
\hline & Health & Self-assessment of the farmer's health. \\
\hline & $\begin{array}{l}\text { Free time } \\
\text { and workload }\end{array}$ & $\begin{array}{l}\text { Aggregate index including the assessment of the amount } \\
\text { of time available to a farmer for activities other than work } \\
\text { on the farm (rest, journey, meetings, deepening knowledge) } \\
\text { and assessment of the feeling of work overload and the fact } \\
\text { of delays in agricultural operations. }\end{array}$ \\
\hline & Stress & $\begin{array}{l}\text { Aggregate index including assessment of the stress level } \\
\text { associated with various aspects of agricultural activity } \\
\text { (debt, failure to keep up with the obligations, } \\
\text { misunderstanding of requirements, changes in regulations, } \\
\text { risks related to weather, other production risks). }\end{array}$ \\
\hline & $\begin{array}{l}\text { Education and } \\
\text { usefulness } \\
\text { of knowledge }\end{array}$ & $\begin{array}{l}\text { Formal level of education and the assessment of the } \\
\text { usefulness of knowledge acquired during education. }\end{array}$ \\
\hline & Successor & $\begin{array}{l}\text { Assessment of the likelihood of the successor taking over } \\
\text { the farm. }\end{array}$ \\
\hline & $\begin{array}{l}\text { Neighbourhood } \\
\text { schemes }\end{array}$ & $\begin{array}{l}\text { Assessment of the tendency of local community members } \\
\text { to help each other. }\end{array}$ \\
\hline
\end{tabular}

Source: own study. 
The applied procedures are in the set of activities often used also by other authors who attempt to construct sustainability indices. As noted by Geniaux et al. (2009), as part of normalisation, it is possible to apply various mathematical transformation procedures that ensure obtaining the desired statistical properties (homoscedasticity, normality, reduction of outliers, non-collinearity, etc.). Salzman (2003) points out that while creating indices, one can use techniques such as operations on raw data (no standardisation, which is justified when using indices reflecting relative relations); normalisation (Z-score, Gaussian normalisation, rescaling), percentage relations and distance measurement in relation to the established objective (established, e.g., by experts). Geniaux et al. (2009) and Mazziotta and Pareto (2013) emphasise that the aggregation of partial indices can take place in various ways (additive, multiplicative, with and without weights, as well as using rules discrete in nature or factor analysis). Rosnobet et al. 2006 (as cited in Bockstaller et al., 2009) indicate that aggregate indices are most often created as an arithmetic mean or weighted average. However, the use of the mean/average requires attention so as not to average the parameters that are not comparable with each other. There are also examples of creating aggregate indices based on monetary or even physical units (e.g. the socalled carbon footprint) (Bockstaller et al., 2009). Binderman et al. (2009) indicate that a non-model synthetic measure, using normalisation of variables with the zero unitarization method, is commonly used in the classification of objects.

Figures 3a-g show the distribution of values of individual partial indices, whereas Figures 3h-k the distribution of the values of indices for three sustainability dimensions and the aggregate level. The presented comparison shows that each of the partial indices quite clearly differentiated the studied collectivity. However, it should be noted that the transition to higher levels of aggregation translates into a reduction in the extent of volatility. Considering, however, that the purpose of this study was not to assess the sustainability of farms, but only to develop and present the index, this text decided to omit the issue of further commenting on the value of sustainability indices. At the same time, it is worth noting that in some cases obtained distribution can be considered close to normal (which is also the effect of the scaling procedure used). 


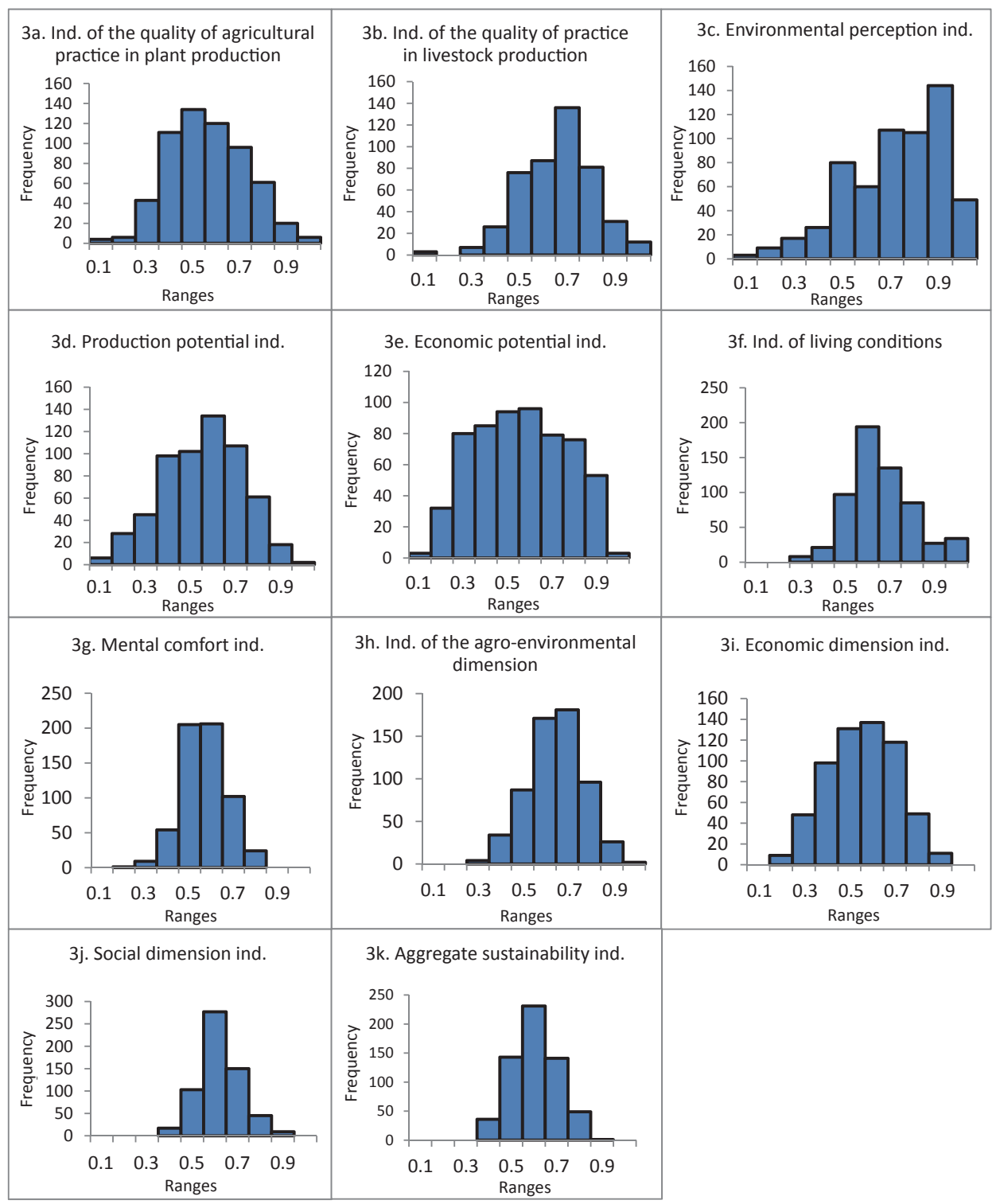

Fig. 3a-i. Distribution of the value of sustainability indices in the studied sample.

Source: own study.

According to the literature on the subject (Babbie, 1995), the variables included in the aggregate index should be correlated with this index. Variables poorly correlated with the whole index may measure a different phenomenon than assumed, therefore, their removal from the index is suggested. Table 4 presents data on the value of the R-Spearman's correlation coefficient between individual partial indices and variables used to create them, as well as correlation coefficients between indi- 
vidual sustainability dimensions and partial indices. During the correlation study, it turned out that several diagnostic variables showed a lack of statistical significance with the indices in the construction of which they were used, and therefore they were eliminated from further analysis and not included in Table 4 (this concerned mainly the indicator of the correctness of agricultural practice in livestock production). In general, the majority of variables turned out to be quite strongly correlated with individual indices.

Table 4

$R$-Spearman's correlation between variables used in the construction of the index and the value of the index (only statistically significant at the p-value level of 0.05$)^{a}$

\begin{tabular}{|c|c|c|c|c|}
\hline 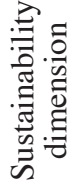 & $\begin{array}{l}\text { Partial } \\
\text { index }\end{array}$ & $\begin{array}{l}\text { Correlations: } \\
\text { sustainability } \\
\text { dimension vs } \\
\text { partial index }\end{array}$ & Diagnostic variable & $\begin{array}{c}\text { Correlations: } \\
\text { partial index } \\
\text { vs diagnostic } \\
\text { variable }\end{array}$ \\
\hline \multirow{21}{*}{ 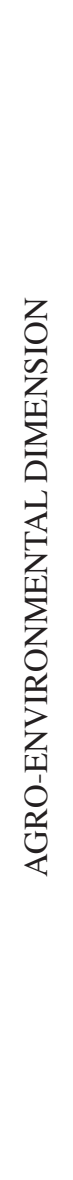 } & \multirow{12}{*}{$\begin{array}{l}\text { Indicator of } \\
\text { the correctness } \\
\text { of agricultural } \\
\text { practice } \\
\text { in plant } \\
\text { production }\end{array}$} & \multirow{12}{*}{0.71} & Soil examination & 0.54 \\
\hline & & & Parameters of chemical plant protection & 0.24 \\
\hline & & & $\begin{array}{l}\text { The basis for determining the mineral } \\
\text { fertilisation dose }\end{array}$ & 0.48 \\
\hline & & & Incorporating manure & 0.30 \\
\hline & & & Catch crops & 0.55 \\
\hline & & & Rules for plant selection & 0.50 \\
\hline & & & Agri-environmental programmes & 0.43 \\
\hline & & & $\begin{array}{l}\text { The basis for the decision on the chemical plant } \\
\text { protection treatment }\end{array}$ & 0.32 \\
\hline & & & Correctness of the use of the sprayer & 0.38 \\
\hline & & & Incorporation of straw & 0.48 \\
\hline & & & Prevention of loss of water from soil & 0.52 \\
\hline & & & Seeds & 0.39 \\
\hline & \multirow{6}{*}{$\begin{array}{l}\text { Indicator of } \\
\text { the correctness } \\
\text { of practice } \\
\text { in livestock } \\
\text { production }\end{array}$} & \multirow{6}{*}{0.56} & Conditions in the livestock building & 0.34 \\
\hline & & & Slipperiness of floors & 0.36 \\
\hline & & & Aggressiveness of animals & 0.23 \\
\hline & & & Separated pens & 0.78 \\
\hline & & & Disinfection of rooms & 0.55 \\
\hline & & & Intensity of stocking & 0.60 \\
\hline & \multirow{3}{*}{$\begin{array}{l}\text { Environmental } \\
\text { perception } \\
\text { indicator }\end{array}$} & \multirow{3}{*}{0.71} & Impact of agriculture on the environment & 0.52 \\
\hline & & & $\begin{array}{l}\text { Knowledge of the concept of sustainable } \\
\text { agriculture }\end{array}$ & 0.68 \\
\hline & & & Environmental requirements & 0.5 \\
\hline
\end{tabular}


cont. Table 4

\begin{tabular}{|c|c|c|c|c|}
\hline 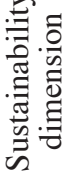 & $\begin{array}{l}\text { Partial } \\
\text { index }\end{array}$ & $\begin{array}{c}\text { Correlations: } \\
\text { sustainability } \\
\text { dimension vs } \\
\text { partial index }\end{array}$ & Diagnostic variable & $\begin{array}{c}\text { Correlations: } \\
\text { partial index } \\
\text { vs diagnostic } \\
\text { variable }\end{array}$ \\
\hline \multirow{14}{*}{ 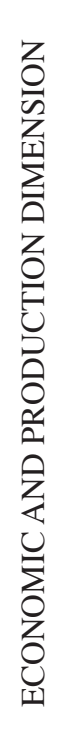 } & \multirow{8}{*}{$\begin{array}{l}\text { Economic } \\
\text { potential } \\
\text { indicator }\end{array}$} & \multirow{8}{*}{0.83} & Property & 0.72 \\
\hline & & & Labour productivity & 0.86 \\
\hline & & & Economic size & 0.89 \\
\hline & & & Area & 0.73 \\
\hline & & & Work profitability & 0.88 \\
\hline & & & Return on capital & 0.57 \\
\hline & & & Stability of income & 0.33 \\
\hline & & & Independence of income from financial support & 0.59 \\
\hline & \multirow{6}{*}{$\begin{array}{l}\text { Production } \\
\text { potential quality } \\
\text { indicator }\end{array}$} & \multirow{6}{*}{0.75} & Soil quality & 0.5 \\
\hline & & & Risk of water and wind erosion & 0.5 \\
\hline & & & Water conditions & 0.42 \\
\hline & & & Content of nutrients in soil & 0.71 \\
\hline & & & Soil acidification & 0.72 \\
\hline & & & Natural sites & 0.3 \\
\hline \multirow{11}{*}{ 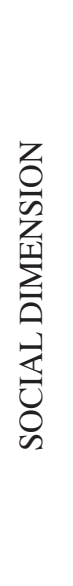 } & \multirow{4}{*}{$\begin{array}{l}\text { Indicator } \\
\text { of living } \\
\text { conditions }\end{array}$} & \multirow{4}{*}{0.84} & Sewage system & 0.56 \\
\hline & & & Gas system & 0.62 \\
\hline & & & Location & 0.40 \\
\hline & & & Housing conditions & 0.51 \\
\hline & \multirow{7}{*}{$\begin{array}{l}\text { Mental comfort } \\
\text { indicator }\end{array}$} & \multirow{7}{*}{0.58} & Social status & 0.38 \\
\hline & & & Health & 0.37 \\
\hline & & & Free time and workload & 0.37 \\
\hline & & & Stress & 0.34 \\
\hline & & & Education and usefulness of knowledge & 0.41 \\
\hline & & & Successor & 0.56 \\
\hline & & & Neighbourhood schemes & 0.36 \\
\hline
\end{tabular}

${ }^{a}$ Only statistically significant at the level of p-value at 0.05 .

Source: own study.

Table 5 shows Spearaman's R correlation between seven individual partial indices. Generally, the strength of the relation between individual indices can be considered quite weak, which justifies the previously emphasised necessity of comprehensive sustainability assessment by referring to its individual dimensions 
(e.g. high assessment in the economic dimension does not necessarily go hand in hand with the correctness of agricultural practice or the social dimension indicators, etc.). However, it is worth noting that correlations in social sciences are essentially weak by their very nature. The correlation between the quality of the practice and the quality of the production potential is relatively high (or medium) - probably due to the habit of good practice, the potential is not degraded. Similarly, knowledge about the impact of agriculture on the environment (perception indicator) correlates significantly (although weakly) with the quality of practice and the potential and indicator of mental comfort. There is also a correlation between the quality of practice and the economic dimension - here, it can be a farm's commerciality or knowledge and skills in the field of running a farm.

Table 5

Correlations between individual partial indicesa

\begin{tabular}{|c|c|c|c|c|c|c|c|}
\hline & 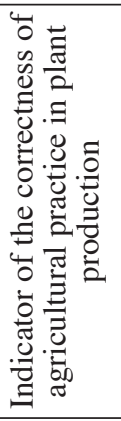 & 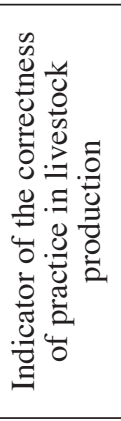 & 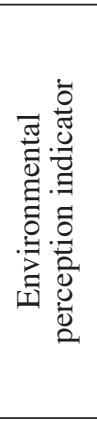 & 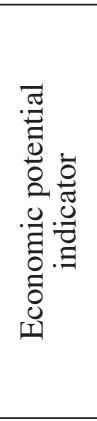 & 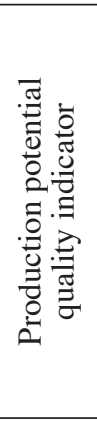 & 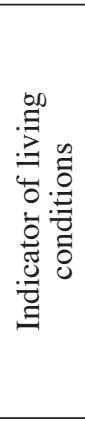 & 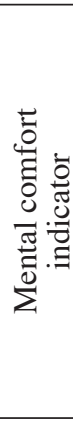 \\
\hline $\begin{array}{l}\text { Indicator of the correctness } \\
\text { of agricultural practice } \\
\text { in plant production }\end{array}$ & 1 & 0.23 & 0.21 & 0.31 & 0.39 & 0.12 & 0.22 \\
\hline $\begin{array}{l}\text { Indicator of the correctness } \\
\text { of practice in livestock } \\
\text { production }\end{array}$ & 0.23 & 1 & & -0.10 & & & \\
\hline $\begin{array}{l}\text { Environmental } \\
\text { perception indicator }\end{array}$ & 0.21 & & 1 & & 0.11 & & 0.09 \\
\hline Economic potential indicator & 0.31 & -0.1 & & 1 & 0.27 & 0.14 & 0.37 \\
\hline $\begin{array}{l}\text { Production potential quality } \\
\text { indicator }\end{array}$ & 0.39 & & 0.11 & 0.27 & 1 & 0.13 & 0.24 \\
\hline Indicator of living conditions & 0.12 & & & 0.14 & 0.13 & 1 & 0.09 \\
\hline Mental comfort indicator & 0.22 & & 0.09 & 0.37 & 0.24 & 0.09 & 1 \\
\hline
\end{tabular}

${ }^{a}$ Correlations irrelevant at p-value 0.05 were removed from the Table.

Source: own research. 


\section{Discussion}

Compared to many previous studies, the applied approach differs in the large number of variables included in development of sustainability indices. The weakness of this type of indices is the need to conduct surveys, which is expensive and time-consuming, because individual data with this degree of detail cannot be obtained from mass statistics databases. For comparison, a comprehensive review of literature on the subject carried out by Hayati (2017) showed that despite the methodological differences between different approaches, the set of parameters, most often used to assess the sustainability of farms in the past studies by different authors, included 9 variables of a social nature, around 14 economic variables and 24 agro-environmental variables. These variables were used in various configurations (and sometimes called differently), but usually their total number used in a single study did not exceed a dozen or so (several per each dimension of sustainability). Similar conclusions can be drawn from a review conducted by van der Werf and Petit (2002). In the Polish literature on the subject, many studies, examples of which were given earlier, are also based on a relatively small number of variables. As indicated by Faber (2007), in the research conducted in the country across farms, the values taken to assess the "sustainability of production" most frequently included farm income, mineral balance, organic matter balance, energy efficiency, soil coverage index and the number of plant protection treatments performed. The analyses of the author quoted show that the selection of indices depended on the type of farms and available data.

The problem of selecting variables both in terms of their number and type remains one of the central issues in the study of sustainable development. This is related to the fact that the concept of sustainability, as emphasised by many authors, is a "social construct" (David, 1989; Webster, 1997; Hayati et al., 2010) and thus the measurement of the phenomena which characterise it is indirect and imprecise. However, this does not change the fact that some variables may quite clearly indicate directions of development of specific phenomena (Hayati et al., 2010). The key challenge here seems to be to identify these easily observable parameters, which can act as an indicator informing about a wider range of phenomena. However, Rigby et al. (2001) emphasises that it is impossible for a single parameter to reflect all relevant information on various aspects of sustainability. In this situation, it can be assumed that the more important parameters covering known aspects of sustainability are included in the structure of the index, the greater its discriminatory power in terms of the actual assessment of sustainability of the farm. In practice, however, there is the problem of obtaining data which allows analysis and assessment of the degree of sustainability - it can be assumed that the larger the number of potential variables, the greater the organisational challenge and the higher the costs of research. One way to extend the set of variables is to combine different types and different sources of data. Recently, the need to aggregate different types of data within the environmental index was indicated by Sabiha et al. (2016). Another problem is the choice of variables for the construction of the index from 
an identified set of available data. As emphasised by Matuszczak (2013, p. 107), "the diversity of sets is rich, which is undoubtedly a difficulty for a researcher (...) and gives signs of subjectivity in the selection of these indices".

One of data sources used more frequently by both foreign and Polish researchers is the FADN database. An example of such analyses is, e.g. research carried out by Wrzaszcz $(2012,2013)$, who in the assessment of environmental sustainability, used diagnostic variables derived from the FADN, such as the number of agricultural plants, the share of cereals, land cover with vegetation in winter, stocking density, balance of organic matter and nitrogen content; and in the assessment of economic sustainability, the relation of farm income to parity income. However, data collected in the FADN database is insufficient to assess social aspects of sustainability. The approach proposed in this article makes it possible to eliminate this problem by extending the data set with a series of variables acquired during interviews with farmers.

Considering the postulate of the need to conduct sustainability analyses in a comprehensive manner noted earlier (Ciegis et al., 2009), it was decided that the undertaken research would include both partial indices constituting certain area aggregates (in order to better organise and understand the original set of variables) and to aggregate them in a further stage into three variables corresponding to three dimensions of sustainability. A similar approach with the separation of intermediate groups of indices (defined as areas) referring to three dimensions of sustainability was adopted, for example, by Thomson and Snadden (2001).

\section{Summary}

As studies of the literature carried out indicate, the implementation of the principles of sustainable development in agriculture requires, in practice, appropriate indices enabling the assessment and monitoring of the state of the sector (and farms) (Faber, 2007). Even though the efforts of many domestic and foreign researchers have so far contributed to the emergence of various concepts of measuring the degree of sustainability of agriculture (farms, production systems), there is still no universal and widely recognised methodology to assess this phenomenon. However, it can be observed that certain sets of variables in different configurations appear in most studies. One of the basic problems in the field of sustainability measurements is the lack of an unambiguous pattern which would guarantee the precision of the assessment. Even if we assume that the desired level of some important parameters can be determined, it should be remembered that the concept of sustainable development is a social construct, in which the interactions between different dimensions of this structure are also important. As it seems, all known studies are only a kind of approximation to the measurement and assessment of the phenomenon in question, which in the current state of knowledge is difficult to assign unambiguous measures and patterns. This study, constituting one more attempt to expand the current state of knowledge in the discussed topic, should also be considered in such categories. Despite many elements shared with other propos- 
als (in particular regarding the selection of diagnostic variables), the methodology proposed in this study differs from the most common approaches in the manner of aggregation of variables and partial indices, and is based on a wide set of variables obtained from various sources.

Bearing in mind that the objective of the article was not to assess the sustainability of farms, but only to present the proposal of the measurement methodology, the issue of the substantive meaning of the results obtained was omitted. However, it can be pointed out that the aggregation of partial indices leads to a decrease in the diversity of the assessed objects along with an increase in aggregation. As a result, it was observed in the conducted analyses that for the majority of the examined objects, the aggregate sustainability index was fairly close to the middle of the range of possible volatility. Bearing in mind that many factors (environmental, economic and social) determine sustainability, it is worth stressing that there is a need to look for measurement methods and assessment methods which would also take into account possible relations (interactions) between these elements. 


\section{References}

Babbie, E.R. (1995). The practice of social research. Belmont: Wadsworth Publishing Company. Baum, R. (2011). Ocena zrównoważonego rozwoju w rolnictwie (studium metodyczne). Rozprawy Naukowe, no. 434, pp. 3-390.

Binderman,Z., Borkowski, B., Szczęsny, W. (2009). O pewnych metodach porządkowania i grupowania w analizie zróżnicowania rolnictwa. Roczniki Nauk Rolniczych, Seria G, vol. 96, issue 2, pp. 77-90.

Bockstaller, C., Stapleton, L.M., Van der Heide, M., Geniaux, G., Bellon, S., Josien, E., Raley, M., Alkan-Olsson, J. (2009). From a disaggregated set of indicators to a synthetic, composite assessment of sustainability: Paths and Pitfalls. AgSAP Conference 2009, Egmond aan Zee, 10-12 March 2009, Netherlands.

Bojarszczuk, J. (2014). Ocena stopnia zrównoważenia gospodarstw mlecznych w oparciu o wybrane wskaźniki produkcyjne i agroekologiczne. Roczniki Naukowe SERiA, vol. XVI(4), pp. 39-44.

Bojarszczuk, J., Księżak, J., Feledyn-Szewczyk, B. (2017). Ocena stopnia zrównoważenia produkcji w gospodarstwach mlecznych według metodyki RISE. Roczniki Naukowe SERiA, t. XIX, issue 2, pp. 27-33.

Carreón, J.R., René, J., Niels, F., Haren van, R. (2011). A Knowledge Approach to Sustainable Agriculture. Global Food Insecurity Rethinking Agricultural and Rural Development Paradigm and Policy. Dordrecht: Springer. DOI: https://doi.org/10.1007/978-94-007-0890-7.

Ciegis, R., Ramanauskiene, J., Martinkus, B. (2009). The Concept of Sustainable Development and its Use for Sustainability Scenarios. Inzinerine Ekonomika-Engineering Economics, nr 2, pp. 28-37.

Cochran, W.G. (1977). Sampling Techniques. New York, Chichester, Brisbane, Toronto, Singapore: John Wiley \& Sons.

Czyżewski, B., Matuszczak, A., Guth, M. (2017). Środowiskowe zrównoważenie gospodarstw rolnych FADN i jego determinanty. Zeszyty naukowe WSES w Ostrołęce, no. 2(25), pp. 192-212.

David, S. (1989). Sustainable development: Theoretical construct on attainable goal? Environmental Conservation, no. 16, pp. 41-48.

Emas, R. (2015). The Concept of Sustainable Development: Definition and Defining Principals. Brief for GSDR.

Faber,A. (2007). Przegląd wskaźników rolnośrodowiskowych zalecanych do stosowania w ocenie zrównoważonego gospodarowania w rolnictwie. W: A. Harasim A. (red.), Sprawdzenie przydatności wskaźników do oceny zrównoważonego gospodarowania zasobami środowiska rolniczego w wybranych gospodarstwach, gminach $i$ województwach. Studia i Raporty IUNG-PIB, no. 5, pp. 9-24.

Feledyn-Szewczyk, B., Kopiński, J. (2015). Ocena zrównoważenia produkcji rolniczej w gospodarstwach uczestniczących w programie rolnośrodowiskowym za pomocą modelu RISE. Roczniki Naukowe SERiA, vol. XVII, issue 2, pp. 45-51.

Geniaux, G., Bellon, S., Deverre, C., Powell, B. (2009). Sustainable Development Indicator Frameworks and Initiatives. Report no. 49, November 2009 of the EU FP6 project SEAMLESS, Ref: PD2.2.1.

Gorlach, K., Klekotko, M., Nowak, P. (2013). Rozwój społeczny - rozwój zrównoważony - postęp: przyczynek do przemian obszarów wiejskich. Wieś i Rolnictwo, no. 3(160), pp. 7-27.

Gómez-Limón, J.A., Sanchez-Fernandez, G. (2010). Empirical evaluation of agricultural sustainability using composite indicators. Ecological Economics, no. 69, pp. 1062-1075.

Harasim, A. (2012). Metodyczne aspekty oceny zrównoważonego rozwoju rolnictwa na różnych poziomach zarządzania W: Problemy zrównoważonego gospodarowania $w$ produkcji rolniczej. Studia i Raporty IUNG-PIB, no. 29(3), pp. 49-64. 
Harasim, A. (2014). Przewodnik do oceny zrównoważenia rolnictwa na różnych poziomach zarzqdzania. Puławy: Wydawnictwo IUNG-PIB.

Harasim, A. Włodarczyk, B. (2016). Ocena zrównoważenia różnych typów gospodarstw na glebach lekkich. Roczniki Naukowe SERiA, vol. XVIII, issue 2, pp. 109-115.

Hayati,D. (2017). A Literature Review on Frameworks and Methods for Measuring and Monitoring Sustainable Agriculture. Technical Report 22. Global Strategy Technical Report: Rome.

Hayati, D., Ranjbar, Z., Karami, E. (2010). Measuring agricultural sustainability. Biodiversity, Biofuels, Agroforestry and Conservation Agriculture. Netherlands: Springer.

Hayo, M.G., Werf van der, H.M.G., Petit, J. (2002). Evaluation of the environmental impact of agriculture at the farm level: a comparison and analysis of 12 indicator-based methods. Agriculture, Ecosystems and Environment, no. 93, pp. 131-145.

Häni, F., Braga, F., Stämpfli, A., Keller, T., Fischer, M., Porsche, H. (2003). RISE, a tool for holistic sustainability assessment at the farm level. IAMA International Food and Agribusiness Management Review, 6(4), 78-90.

Kalton, G. (1983). Introducing to Survey Sampling. Sage Publications.

Kania, J., Kapłon, A. (2014). Zrównoważenie produkcji rolniczej w wybranych gospodarstwach województwa małopolskiego. Roczniki Naukowe SERiA, vol. XVI, issue 4, pp. 134-140.

Krasowicz, S. 2009: Rola oceny ekonomicznej w badaniach rolniczych. Journal of Agribusiness and Rural Development, no. 2(12), pp. 93-99.

Krasowicz, S., Kuś, J. (2010). Kierunki zmian w produkcji rolniczej w Polsce do roku 2020 próba prognozy. Zagadnienia Ekonomiki Rolnej, no. 3(324), pp. 5-18.

Kuś, J., Krasowicz, S. (2001). Przyrodniczo-organizacyjne uwarunkowania zrównoważonego rozwoju gospodarstw rolnych. Pamiętnik Puławski, no. 124, pp. 273-288.

Latruffe, L., Diazabakana, A., Bockstaller, C., Desjeux, Y., Finn, J. (2016). Measurement of sustainability in agriculture: a review of indicators. Studies in Agricultural Economics, $n r$ 118(3), pp. 123-130.

Longhitano, D., Bodini, A., Povellato, A., Scardera, A. (2012). Assessing farm sustainability. An application with the Italian FADN sample. Paper prepared for presentation at the $1^{\text {st }}$ AIEAA Conference: Towards a Sustainable Bio-economy: Economic Issues and Policy Challenges, 4-5 czerwca 2012, Trento, Włochy.

Lusawa, R. (2012). Trwały rozwój w skali regionalnej i lokalnej. Koncepcja $i$ działania. Warszawa: Wydawnictwo Wieś Jutra.

Majewski, E. (red.) (1997). System Integrowanej Produkcji Rolniczej. Wytyczne i instrukcja wdrożeniowa. Warszawa: Fundacja Rozwój SGGW.

Majewski, E. (2001). Jakość zarzadzania w gospodarstwach rolniczych w Polsce w świetle badań. Warszawa: Wydawnictwo SGGW.

Majewski, E. (2008). Trwały rozwój i trwałe rolnictwo - teoria a praktyka gospodarstw rolniczych. Warszawa: Wydawnictwo SGGW.

Matuszczak, A. (2013). Wskaźniki zrównoważonego rozwoju rolnictwa. Przesłanki teoretyczne i propozycja pomiaru w regionach UE. Wieś i Rolnictwo, no. 1(158), pp. 101-119.

Mazziotta, M., Pareto, A. (2013). Methods for constructing composite indices: one for all or all for one?. Rivista Italiana di Economia Demografia e Statistica, vol. LXVII n. 2 AprileGiugno 2013, pp. 67-80.

Meulen van der, H.A.B., Dolman, M.A., Jager, J.H., Venema, G.S. (2014). The Impact of Farm Size on Sustainability of Dutch Dairy Farms. $19^{\text {th }}$ International Farm Management Congress, SGGW, Warszawa, Polska. 
MRiRW, MŚ (2004). Kodeks Dobrej Praktyki Rolniczej. Warszawa.

OECD (2002). Glossary of statistical terms. Multi-Phase Sampling. Retrieved from: www.stats. oecd.org/glossary/detail.asp?ID=3725.

Olde de, E.M., Oudshoorn, F.W., Sørensen, C.A.G., Bokkers, E.A.M., Boer de, I.J.M. (2016). Assessing sustainability at farm-level: Lessons learned from a comparison of tools in practice. Ecological Indicators, no. 66, pp. 391-404.

Olsson, J.A., Bradley, K., Hilding-Rydevik, T., Ruotsalainen, A., Aalbu, H. (2004). Indicators for Sustainable Development. Paper for discussion. European Regional Network on Sustainable Development.

Ostasewicz, S., Rusnak, Z., Siedlecka, U. (2011). Statystyka. Elementy teorii i zadania. Wrocław: Wydawnictwo Uniwersytetu Ekonomicznego we Wrocławiu.

Rigby, D., Woodhouse, Ph., Young, T., Burton, M. (2001). Constructing a farm level indicator of sustainable agricultural practice. Ecological Economics, no. 39, pp. 463-478.

Rosales, C.J., René, J., Niels, F., van Haren, R. (2011). A Knowledge Approach to Sustainable Agriculture. Retrieved from: www.springer.com/978-94-007-0889-1.

Sabiha, N., Salim, R., Rahman, S., Rola-Rubzen, M.F. (2016). Measuring environmental sustainability in agriculture: A composite environmental impact index approach. Journal of Environmental Management, no. 166, pp. 84-93.

Sachs,I. (2011).Trzeci brzeg. W poszukiwaniu ekorozwoju. Warszawa: Wydawnictwo Uniwersytetu Warszawskiego.

Salzman, J. (2003). Methodological Choices Encountered in the Construction of Composite Indices of Economic and Social Well-Being. Ottawa: Center for the Study of Living Standards.

Thomson, K., Snadden,A. (2001). Rural Development Committee: Developing a framework for assessing the contribution to rural sustainability of public policy in support of agriculture, University of Aberdeen. Commissioned by the Scottish Parliament Information Centre for the Rural Development Committee.

Toczyński, T. Wrzaszcz,W.,Zegar,J.S.(2013).Zrównoważenie polskiego rolnictwa. Powszechny Spis Rolny 2010. Warszawa: GUS.

Wąs, A. (2013). Modelowanie przemian strukturalnych polskiego rolnictwa. Warszawa: Wydawnictwo SGGW.

Webster, J.P.G., (1997). Assessing the economic consequences of sustainability in agriculture. Agriculture, Ecosystems and Environment, no. 64(2), pp. 95-102.

Werf van der, H.M.G., Petit, J. (2002). Evaluation of the environmental impact of agriculture at the farm level: a comparison and analysis of 12 indicator-based methods. Agriculture, Ecosystems and Environment, no. 93, pp. 131-145.

World Commission on Environment and Development (1987). Our Common Future. Oxford: Oxford University Press.

Wrzaszcz, W. (2012). Poziom zrównoważenia indywidualnych gospodarstw rolnych w Polsce (na podstawie danych FADN). Studia i Monografie, no. 155. Warszawa: IERiGŻ-PIB.

Wrzaszcz, W. (2013). Zrównoważenie indywidualnych gospodarstw rolnych w Polsce objętych FADN. Zagadnienia Ekonomiki Rolnej, no. 1(334), pp. 73-90.

Zacher, L.W. (2008). Trwały rozwój - utopia czy realna możliwość?. Problemy Ekorozwoju. vol. 3 , no. 2 , pp. 63-68.

Zhen, L., Routray, J.K. (2003). Operational indicators for measuring agricultural sustainability in developing countries. Environmental Management, no. 32(1), pp. 34-46.

Żylicz, T. (2008). ,Silna” trwałość rozwoju. Aura, no. 6. 


\title{
TWORZENIE WSKAŹNIKA TRWAŁOŚCI (SUSTAINABILITY) GOSPODARSTW ROLNYCH NA PODSTAWIE BADAŃ ANKIETOWYCH I PRÓBY FADN
}

\begin{abstract}
Abstrakt
Artykut ma charakter metodyczny. Omówiono $w$ nim procedure opracowania wskaźnika trwałości gospodarstw rolnych, wykorzystujac dane pochodzqce $z$ badań ankietowych oraz dane rachunkowe zgromadzone $w$ bazie systemu FADN. Badaniami objęto łącznie 600 gospodarstw dobranych w sposób analogiczny do doboru stosowanego w FADN (biorac pod uwage wielkość ekonomiczna, typ produkcyjny oraz region). W konstrukcji wskaźnika trwałości gospodarstw wykorzystano zmienne charakteryzujace środowiskowy, ekonomiczny $i$ społeczny wymiar trwałości. Łacznie w ocenie trwałości zastosowano ponad 100 parametrów wyjściowych sklasyfikowanych $w 7$ wskaźnikach czastkowych. Uzyskany rozkład poszczególnych wskaźników czastkowych i wymiarów trwałości wskazuje na zróżnicowanie badanej zbiorowości pod względem rozpatrywanych parametrów. Jednocześnie stwierdzono, że agregacja prowadzi do dominacji wartości bliskich środka przedziału rozpatrywanych wskaźników. Zastosowana metodyka umożliwia ocene trwałości poszczególnych gospodarstw i ich klasyfikację do grup obiektów zróżnicowanych pod względem zgodności z zasadami zrównoważonego (trwałego) rolnictwa. Możliwość pomiaru i oceny trwałości gospodarstw można uznać za pierwszy krok w procesie kreowania skutecznych polityk wsparcia rozwoju rolnictwa. Artykuł stanowi głos $w$ toczacej sie od wielu lat dyskusji na temat operacjonalizacji koncepcji trwałego rozwoju i sposobów pomiaru stopnia zgodności działań podmiotów gospodarczych z przywołanym paradygmatem.
\end{abstract}

Słowa kluczowe: trwały rozwój, trwałe rolnictwo, pomiar trwałości.

Accepted for print: 5.09.2018.

Unless stated otherwise all the materials on the website are available under the Creative Commons Attribution 4.0 International license.

Some rights reserved to the Institute of Agricultural and Food Economics - National Research Institute.

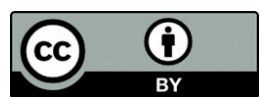

